\title{
Bees on paper: the British press reads the Fable
}

\author{
MATTEO REVOLTI \\ Goethe University Frankfurt am Main
}

\begin{abstract}
The British press played a significant role by influencing public debates following the publication of Mandeville's The fable of the bees. Between 1714 and 1732, British newspapers published over three hundred reports on the Fable that circulated in the form of editorials and advertising announcements. These publications not only offered general information on the Fable, they also fueled controversy surrounding Mandeville's text. In this article I will analyse how the British press introduced the Fable to its readers and influenced its reception. Specifically, my aim is to show how the Fable's reception was shaped by the political and economic orientation of the newspapers in question. In doing so, I will analyze appearances of the Fable and its critics in the British press. I will then examine the language and topics used by two popular essay-papers, the Mist weekly journal and the Craftsman, who presented Mandeville's book.
\end{abstract}

Keywords: newspapers, advertisings, Nathaniel Mist, Robert Walpole, Jonathan Wild, South sea bubble

Bernard Mandeville submitted his last publication, A letter to Dion, to the printer James Roberts in 1732. In this seventy-page essay, the Dutch author responded to George Berkeley, who had attacked the Fable in his Alciphron or the minute philosopher (1732). Mandeville ironically maintained that the Irish bishop had not read a single page of his work but only reproduced the criticisms of the Fable set forth in sermons and newspapers. Indeed, the Berkeleian condemnation of Mandevillean topics, such as the celebration of vices or the notion of human nature, had been adopted and discussed by the British public opinion in the years before. Specifically, newspapers were responsible for making the

AUTHOR's NOTE: An earlier version of this paper was submitted for the 300th anniversary of the publication of The fable of the bees and the centennial of Erasmus University. I would like to thank Harro Maas, Laurens van Apeldoorn, and Johan Olsthoorn for organizing the conference 'Science, politics and economy. The unintended consequences of a diabolic paradox' held at the Erasmus University Rotterdam on 6 June, 2014. 
Fable well-known among the public, frequently casting it as an attack upon religion and public spirit. From Mandeville's point of view, the press had published misleading editorials about his book and thus compromised its reception. The Dutch author complained in particular about the increasing influence enjoyed by newspapers, noting ironically that "if we find the London Journal have a Fling at the Fable of the bees one Day, and The craftsman another, it is a certain Sign that the ill Repute of the Book, must will be established and not to be doubted of" (Mandeville 1732, 6). Mandeville's claim was intended to vilify one of the more salient aspects of English society: the newspaper industry.

Very little research has been done on the reception of the Fable in the British press. Kaye's classical edition of the Fable provides a partial list of newspaper articles on the Fable (Mandeville 1924, II: 418-426). In his critical study, Martin Stafford (1997) cites only eight articles. This paper argues that newspapers played a crucial role in the debate triggered by Mandeville's work in four ways. Firstly, the press provided step by step reporting on the origin and development of the discussion surrounding Mandeville's text. For instance, the Evening post printed the presentment by the Grand Jury of Middlesex on 11 July 1723. Mandeville's response to the aspersions cast on his book appeared in the London journal of 10 August 1723. Secondly, some of the Fable's critics used the press to attack the work of the Dutch author. For example, Francis Hutcheson attacked the Fable in the Dublin weekly journal and London journal several times. In addition to these critiques, the newspapers also published false news items regarding the Fable, such as Mandeville's supposed abjuration of his opinions in $1728 .{ }^{1}$ Finally, in many cases the press was unabashedly biased. Newspapers representing opposing political views often offered contradictory interpretations of Mandeville, always casting him as contrary to their own positions (some as a Whig, others as a Tory, etc.).

\section{THE FABLE AND THE BRITISH NEWSPAPERS}

During the restoration of Charles II, the press was regulated by the Licensing Act, which specified that every publication had to be licensed and supervised by the Stationer's Company. The only paper to hold this

\footnotetext{
${ }^{1}$ On Saturday, 9 March 1728, the London evening post printed the following note: "On Friday Evening, the first Instant, a Gentleman well-dress'd, appeared at the Bonfire before St. James's Gate, who declared himself the author of the Fable of the Bees: And that he was sorry for writing the same: and recollecting his former Promise, pronounced this Words: I commit my Book to the Flames; and threw it in accordingly".
} 
authorization was the London gazette, which served as the official organ of government and was printed in a single sheet twice weekly. Following the lapsing of the Licensing Act in 1695, there was an upsurge of newspapers and periodicals in England and its provinces (Plomer 1922; Siebert 1965; Black 1987; Harris 1987; Clark 1994; Raymond 1999; Heyd 2012). Between May and October 1695, three tri-weekly newspapers appeared: the Flying post, the Post boy, and the Post man, all of which were delivered to the local postmaster. Under the reign of Queen Anne the first daily, the Daily courant (1702), was printed; in August 1706 the first evening paper, the Evening post, appeared. Generally, newspapers were edited and published by printers who also printed books, pamphlets, ballads, etc. They circulated in taverns, coffee-houses, and clubs, and informed their readers about domestic and foreign news; in some cases, they offered commentary on political, moral, and economic topics as well. The rapid expansion of the press was followed by the growth of the printing industry, which often combined commercial and political interests. In 1724, the printer Samuel Negus offered Lord Viscount Townshend a complete list of all the printing-houses in London (Nichols 1812-1815, I: 288-312). The list not only gave an account of the printers, it also informed Townshend of the political stances of the publishers. For instance, the printer Roberts was known "to be well affected to King George" (Nichols 1812-1815, I: 292), whereas the printer of the Evening post was a "Roman catholick" (Nichols 18121815, I: 312). Consequently, many newspapers were connected to political parties and they quickly assumed Whig or Tory associations: the Daily courant from London was a Whig publication, whereas the Post boy was an organ of the Tory party. ${ }^{2}$ According to Speck and Holmes $(1967,2)$, in the early eighteenth century the press was the most effective instrument of party propaganda in Great Britain. The newspapers constituted an important means of evaluating the extent to which popular opinion supported or opposed a particular issue. Many papers were sponsored by politicians, as demonstrated by Bolingbroke's support of The craftsman journal, or the editing of the Mist weekly journal by the Jacobite, Nathaniel Mist.

Given this context, the reception of the Fable was at times influenced by the political affiliation of the papers. Mandeville himself denounced

\footnotetext{
${ }^{2}$ Whereas in Anne's reign the metropolitan newspapers followed the classic distinction in Whig and Tory, under the kingdom of George II they tend to divide into government and opposition (Speck 1986, 48).
} 
the contradictions of "our party writers" $(1732,6)$, which he saw as disparaging to his work. Indeed, the press not only provided an account of the controversy sparked by the Fable, it also provided its readers with various interpretations of the debate. First, the newspapers purposely misrepresented Mandeville's text, publishing the most provocative passages of his work. The denial of virtues, the legalization of prostitution, and the praise of self-interest were the most popular Fable quotes published in the papers. Secondly, the press associated the Fable with several specific issues. For instance, the Tory press presented the Fable's content in association with certain negative topics such as the South sea bubble or the thief Jonathan Wild; on the other hand, the Whig newspapers emphasized the coexistence of virtues and commerce, denying the Fable's motto, private vices, public benefits. It is thus clear that newspapers of the time represent a key piece in the puzzle of the debate surrounding the Fable.

\section{THE FIRST NOTICES REGARDING THE FABLE}

The first notice about Bernard Mandeville in the British press appeared on 18 January, 1704, in the Post man and the historical account; the newspaper, under the direction of Richard Baldwin, advertised an edition of Aesop dress'd or a collections of fables written by B. Mandeville MD. ${ }^{3}$ Another reference to the Dutch author was then occasioned by Mandeville's Treatise of the hypochondriack and histeryck passions in 1711. On 27 December, 1711, the Post man expanded the notice, publishing the Dutch physician's London address as it appeared on the frontispiece of the Treatise. ${ }^{4}$ On 7 December, 1714, the Post man also announced the publication of The fable of the bees. According to Mandeville, the metropolitan press only began to pay serious attention to the Fable after the Grand Jury's indictment in July of 1723. In the

\footnotetext{
${ }^{3}$ Other works of Mandeville were advertised between 1704 and 1711, but most of them appeared anonymously. For instance, on 18 April, 1704, the Daily courant advertised Typhon or the wars between the gods and giants; on 2 April, 1705, the Grumbling hive was promoted by the Daily courant, and on 23 November, 1709, the Virgin unmask'd was advertised by the Observator.

${ }_{4}$ "A Treatise of the Hypochondriack and Hysterick Passions, vulgarly call'd the Hypo in Men and Vapours in Women; in which the Symptoms, Causes, and Cure of those Diseases are set forth, after a Method entirely new. The whole interspers'd, with Instructive Discourses on the real Art of Physick itself; and entertaining Remarks on the modern Practice of Physicians and Apothecaries: Very useful to all, that have the Misfortune to stand in need of either. In 3 Dialogues. By B. de Mandeville, MD. To be had of the AUTHOR, at his House in MANCHESTER COURT, in Channel-Cow, Westminster [...] just published".
} 
third edition of the Fable, he complained that "the first Impression of the Fable of the Bees, which came out in 1714, was never carpt at, or publickly taken notice of" (1924, I: 473). As Speck remarked (1978, 1), the first edition of the Fable attracted some readers, but indeed does not appear to have excited much comment. Nevertheless, there were some reports on the Fable circulating between 1718 and 1722. For instance, on 15 October, 1719, the Evening post advertised the re-release of "the celebrated poem of the Fable of the Bees". On 7 August, 1722, the Post man advertised both the Fable of the bees and Free thoughts, informing its readers that both had been written by Dr. Mandeville. As a result, it was public knowledge that Mandeville had written the Fable from at least 1722 onwards; it thus stands to reason that Mandeville's Fable was reasonably well known prior its 1723 second edition.

On 11 July, 1723, the indictment of the Grand Jury against the Fable was inserted in the Evening post and Mandeville's book suddenly attracted widespread attention in the British media. This was shortly followed by an increase in both reports on the Fable as well as attacks against it. On 27 July, 1723, the London journal published an anonymous letter addressed to Lord C. praising the politics of the current government against the infidelity: under the pseudonym of Theophilus philo-britannus, the author suggested that the Fable and three Cato's letters were supporters of the Pretender. In addition, the correspondent of the London journal maintained that the texts in question undermined the current government and the protestant succession:

My Lord,

'TIS Welcome News to all the King's Loyal Subjects and true Friends to the Establish'd Government and Succession in the Illustrious House of Hanover, that your Lordship is said to be contriving some Effectual Means of securing us from the Dangers, wherewith his Majesty's happy Government seems to be threatened by Catiline, under the Name of Cato; by the Writer of a Book, intituled, The Fable of the Bees, \&c. and by others of their Fraternity, who are undoubtedly useful Friends to the Pretender, and diligent, for his sake, in labouring to subvert and ruin our Constitution, under a specious Pretence of defending it.

The name adopted by the reporter contains a clue that might better illuminate his political background and stance. ${ }^{5}$ Indeed, the pseudonym

\footnotetext{
${ }^{5}$ The pseudonym of Theophilus Philo-Britannus only appeared in the article at issued.
} 
appears to refer to Britannicus, a name employed by the English bishop Benjamin Hoadly. Walpole bought the London journal in 1722 and entrusted it to Hoadly, who had always been a loyal supporter of the protestant succession and the Whig party (Sanna 2012, 88-101). From 1722 to 1724, Hoadly was the editor of the London journal and, under his direction, it became the mouthpiece of Walpole and Townshend's government. Theophilus could very well have been a member of Hoadly's entourage, which defended the Whig government from the charges brought by its enemies. It would thus make sense for Theophilus to cast the Fable in opposition to the Whig party, thereby affirming that Mandeville's text had more in common with the hated Jacobite party instead. On 10 August, 1723, Mandeville replied to Theophilus from the London journal in an effort to defend his work, asserting that, "I think myself indispensably obliged to vindicate the above-said Book against the black Aspersions that undeservedly have been cast upon it".

At the beginning of the "battle of the bees" (Schneider 1987, 101), the press influenced the public reception of the Fable through its advertisements. For instance, on 17 August, 1723, the British journal advertised an essay by the reverend William Hendley, entitled A defence of charity schools. In his Defence, the first response to Mandeville to be advertised by newspapers, the reverend from Islington aimed to defend charity schools from the attacks mounted by the Fable and Cato's letters. Although the Defence was not published until the following year due to a long sickness suffered by the English reverend, the advertisement not only promoted Hendley's text but also called the Fable an atheistic book:

A very Reverend and very Learned Divine hath undertaken, in two Months, to answer the Objections made by Cato, and the Author of the Fable of the Bees, against the present Management of the CharitySchools. This elaborate Performance is to be printed by Subscription; and, considering the Qualifications of the Author, 'tis not doubted but that there will be great Contributions to this Work of Charity; for who is so well qualify'd to prove these Authors to be Atheist, or anything else, as one, who, in the latter End of the late Reign, publish'd a Sermon, entitled, Whigs no Christians? Who a more proper Advocate for the Teachers in these Schools!

The British journal concluded the advertisement by reminding readers of a sermon of Hendley's called Whigs no Christians. This 
sermon was delivered in 1713, in Putney, on the anniversary of the martyrdom of Charles I. In it, Hendley defended the divine right of kings whose sovereignty had been established by God: given the divine nature of his power, Hendley argued, the king could not be deposed because of the disparity between him and common citizens. According to Hendley, citizens have no independent rights and must submit to the authority of the sovereign. The sermon therefore denied the right of resistance and asserted that the rebels must be banished from the Church of England. Among the rebels listed, the sermon also included the Whigs and LowChurchmen as people who should be excluded from the church and denied the label of Christian. As Hendley remarked, "But such Men as these (nowadays known by the name of Whigs, or Low-Churchmen) [...] should they be excluded the Pale of the Church, and be denied the Denomination of Christians, and ranked among Jews or Heatens" (1713, 5). By mentioning Hendley's sermon, the British journal associated Mandeville's A defence of charity school with the Jacobite stance taken by Hendley, whose previous sermon was the main sponsor for the Pretender. The British journal thus encouraged its readership to view the Fable as somehow connected to the Whig pamphlets that Hendley had denounced in his earlier sermon. In doing so, the newspaper indirectly yet effectively framed the Fable, alongside Cato's letters, as belonging to the body of Whig literature condemned by the Jacobite pastor.

\section{THE BEES IN GREAT CARTER LANE: NATHANIEL MIST AND THE FABLE}

The following year the Fable began to attract significant public attention. Firstly, Mandeville's text was no longer associated with Cato's letters; rather, it was considered as an independent book. Secondly, the criticisms addressed to Mandeville were not exclusively focused on the Essay on charity and charity schools but referred to the whole text of the Fable. ${ }^{6}$ Mandeville used the notoriety gained by the Fable to promote his new publications: a third edition of the Fable, A modest defence of publick stews, and reprint of The virgin unmask'd. Despite these efforts, however, Mandeville's name initially appeared in the newspapers due to his publication Free thoughts (1722). On 30 May, 1724, the British journal's correspondent addressed a letter to Crito containing a long extract from Mandeville's work. The journalist, under the pseudonym of

\footnotetext{
${ }^{6}$ The early criticisms of Mandeville's text appeared within a few months: in January the newspapers advertised William Law's Remarks; a month later Richard Fiddes published his Treatise; and finally, in April the Daily journal publicized John Dennis' essay.
} 
B.A, complained about the scarce interest in the Free thoughts, even though Mandeville's work had been translated into French. ${ }^{7}$ Within this context, the Mist weekly journal, one of the papers most critical of Mandeville's text, offered readers a curious interpretation of the Fable. The essay-paper was linked to Nathaniel Mist, a British printer who explicitly opposed the Whig party. In Samuel Negus's list, the publisher of the "scandalous Weekly journal" (Nichols, 1812-1815, I: 311) was included among the Jacobite printers, and indeed Mist was repeatedly tried by the government for sedition. $^{8}$ On 8 August, 1724, Mist published a review of A modest defence of publick stews, suggesting that the author of $A$ modest defence was the very same man who had written the Fable. In addition, the publisher of the Weekly journal maintained that Mandeville was an admirer of the Dutch Republic, a position that could be seen from his plan to open public stews in London modeled after the Dutch ones:

The Treatise intitled The Fable of the Bees, perhaps, has as much good and bad Reasoning in it as ever were seen in the Writings of the same Author. This Gentleman I take to be the first among us who has argued for a publick Toleration of Vices. He seems a great Admirer of the Policies of the Dutch [...].

The following year Mist's journal changed its name to Mist weekly journal. On 19 June, 1725, the Mist' published a brief account of the life of the famous thief-taker and criminal, Jonathan Wild, based on a semisatirical biography published some weeks after Wild's death. In his account, the Mist' reporter stressed that the thief-taker belonged to the political and cultural background of the Whig party. Firstly, Wild was introduced as a freethinker "and a little inclin'd to Atheism"; secondly, he was presented to be as supporter of the Whig party and its motto "keep what you get and get what you can". In particular, the reporter highlighted Wild's plan to write an essay entitled, De legibus naturae, in

\footnotetext{
7 "Give me, therefore, leave to present you with a very good Paper out of an excellent Book, too little known. It is Dr. Mandeville's Free Thoughts on Religion, \&c. To the Reproach of our Taste, it has been twice translated into French, and yet is scarce known in England. It was written for the Interest of the Establishment; and yet the Friends of the Establishment have, for want of reading it, not promoted it".

${ }^{8}$ In December 1716, Mist bought the Weekly journal from Robert Mawson, changing its name to Weekly journal or Saturday's post. As Harris remarked (2003, 51), this periodical was published in the famous Great Carter lane, which was situated on the south side of St. Paul Cathedral and included several important coffee houses like the celebrated Lloyd.
} 
which the notorious double-dealer intended to legitimise all kind of knavery as virtuous and honorable actions:

He communicated to me a Design he had of getting a Treatise wrote De Legibus Naturae; under which Title, Theft and all Kinds of Knavery should be recommended as vertuous and honourable Actions; and that they were justifiable by Laws of Nature, which teach us to seek own Good; and that he intended to employ the ingenious Pen of the Author of the Fable of the Bees for that Purpose, whom he look'd upon to be equal to the Subject.

The Mist' thus associated Mandeville with a wicked and depraved element of English society in the figure of Wild. Both the Fable and the thief-taker were identified by the Jacobite journal as the main sponsors of the Whig party, a party which was considered to be the author of all criminal and dishonest activities.

At the same time, the Mist' also paid a great deal of attention to the Fable's critics and often adopted their claims against Mandeville's book. On 11 June, 1726, for instance, a Mist' reporter informed his readership of how he and his friend had been offended by "a Book entitled, The Fable of the Bees; or, Private Vices Publick Benefits, and it has been Matter of great Grief to us, to see a Person so hardy as openly to write in Defence of Vice". In response to the Fable, the two Mist' journalists held up Law's Remarks and The enquiry whether a general practice of virtue tends to the wealth or poverty as the main bulwarks standing in opposition to Mandeville's text. In particular, the Mist' reporter praised the recent publication of the anonymous treatise, True meaning of the fable of the bees:

[...] and as Auxiliaries, we sent for every Answer to the Fable of the Bees which our News Papers gave us Notice of. And much Ground did we get by the Assistance of two Pieces, the one entitled, Remarks on the Fable of the Bees, \&c. The other, An enquiry whether a general Practice of Virtue tends to the Wealth or Poverty, Benefit or Disadvantage of a People \&c. [...] This, Sir, has hitherto been our Case, but now do we prepare for Victory, and compleat Conquest, we have met with a Book, entitled The true Meaning of the Fable, \&c. and we venture to say, that it really is the True meaning of the Fable of the Bees, and that it has set that perplex Book, in its just, and proper Light. 
According to True meaning, the Fable aimed to enrich only a small part of the nation while enslaving the rest of society. Although the Dutch author pretended to write for the benefit of the multitude, it claimed, he actually supported an arrangement in which the poor would be forced into the position of badly paid labourers. This position motivated his continuous attacks on institutions, such as the charity schools, the clergy, and the universities. The Mist' journalist concluded, in a comment addressed to Nathaniel Mist, by saying "now, Sir, if you are of my Sentiments, and think the True Meaning, \&c. has set the Author which opposes it, in a just Light, [...] give this a Place in your Paper".

Another interesting reference to the controversy around Mandeville's text appeared some months early. On 5 March, 1726, the Mist advertised the recent publication of True meaning, informing its readership that the text had been conceived of as a response to Bluet's Enquiry. Although the authorship of the Enquiry is a vexed question (Sakmann 1897, 125; Kaye 1921, 461-462; Carrive 1980, 26; Stafford 1997, 229), the Mist reported the death of its author:

There was publish'd this Week, a Defence of the Fable of the Bees in the form of a Letter, to the Author of an Enquiry, \&c. whose Death has been mentioned in this paper some time since, with his deserv'd Praise. It is submitted to the Publick to determine, whether the Greatness of the Performance, or other prudential Considerations, were true Cause that induce this Writer to delay his Letter 'till after the Decease of the Person whom it was directed. Or whether or no, if this Insult on the Dead should awaken one of them to come and shew him the Inquiry and Baseness of his Purposes, he would repent.

\section{BETWEEN PHILANTROPOS AND THE SECOND PART OF THE FABLE}

The Fable's critics themselves also used the press to advertise their work. On 14 November, 1724, Francis Hutcheson, under the pseudonym of Philantropos, published an announcement in the London journal for his essay, An inquiry into the original of our ideas of beauty and virtue. In the article the Scottish-Irish philosopher included some passages from his work defending the Shaftesbury's moral system. Two years later, Hutcheson wrote a series of articles in the Dublin weekly journal that presented, in advance, some of the passages found in his later Reflections upon laughter, and observations upon the Fable of the bees (1750). In three of these articles Hutcheson criticized Mandeville's views, maintaining that virtue and commerce were compatible and luxury did 
not necessarily lead to vice. ${ }^{9}$ In 1729 he went on to write some articles for the London journal, the periodical that served as the mouthpiece of the finance community. Under the Walpole government the London newspaper promoted financial speculation, encouraging speculators and businessmen to engage in these kinds of market transactions. Mandeville's assertion that only vices enriched society was thus seen as a danger of the practice of speculation. Hutcheson himself followed the London journal's logic, emphasizing the necessity of overcoming outdated moral prejudice regarding commerce. In keeping with this position, he criticized the pessimism expressed by the Fable concerning the relationship between virtues and commerce. As Hutcheson noted in the London journal editorial on 14 June, 1729:

What our Author seems to mean by Private Vices Publick Benefits, is, that all the Villainies, Extravagance, Intemperance, Luxury, and Pride, of Individuals, tend to Publick Happiness of Society, and to increase the Power and the Grandeur of any Nation [...] To silence this Writer therefore intirely, must be to take him to Task in his own Way; and if it can be fully proved that there may be an Equal, nay a greater Consumption of Manufactures without these Vices and Evils, which flow from them: that Wealth and Power do not naturally tend to Vice or necessarily produce it; then it will be unjust to conclude, either, that Vices naturally tend to Publick Prosperity, or are necessary to it; or that Publick Happiness does necessarily occasion them.

Finally, a section of Hutcheson's Inquiry was published in the Read's weekly journal or, British gazetteer on 1 April, 1732. This section addressed the distinction between benevolent and selfish man, and included some references to Mandeville's work. Within the debate sparked by Mandeville's text, relatively few references were focused on the second part of the Fable that was published in 1729. According to Mandeville, the Part II aimed to clarify some of the topics dealt with in his earlier writing; in particular, in this work the Dutch author introduced and developed the notion of self-liking, which was presented as the principal motive of human actions (Simonazzi 2008; Tolonen 2013). Between 1729 and 1733, the only periodical to provide a brief account on Mandeville's work was the Echo or Edinburgh weekly journal. On 28, May, 1729, the Scottish paper advertised that:

\footnotetext{
${ }^{9}$ In the articles on Dublin weekly journal Hutcheson used the acronym of P.M.
} 
A second Part of the Fable of the Bees, by the author of the first; a Book that has made so much Noise, wherein humane Nature is further considered, both in its individual and social State, and all the several Ranks and Degrees thereof, from that of the first Minister, to that of the lowest subject, througly anatomiz'd and unfolded: Wherein, especially a very particular Deference and Regard is paid to the Beau monde, and the true Merit and great Excellence of all their glaring and shining Vertues, plac'd in the most clear and conspicuous Light. Together with a Confutation of the late Earl of Shaftesbury's System, as delivered in the Characteristicks on those Subjects, and an Answer to many Doubts and Difficulties of the Deist against Christian religion, and to several Objections that were made against the first Part.

Ultimately, reports on the Fable circulated until the death of the Dutch physician. ${ }^{10}$ The last reports on Mandeville were printed on the occasion of his death in January 1733. An obituary was published in the Daily journal on Tuesday, 23 January. It praised Mandeville for his professional contributions and loyalty to his friends. Perhaps Mandeville's death was the last occasion for reconciliation between the author of the Fable and the newspapers that had long opposed him:

On Sunday Morning last died at Hackney, in the 63d Year of his Age, Bernard Mandeville, M.D: Author of the Fable of the Bees, of a Treatise of the Hypochondriac and Hysteric Passions and several other curious Pieces, some of which have been translated and publish'd in Foreign Languages. He had an extensive Genius, uncommon Wit, and strong Judgment. [...] In his Profession he was of known Benevolence and Humanity; in his private Character, a sincere Friend; and in the whole Conduct of Life, a Gentleman of great Probity and Integrity.

\section{A DEFENSE OF WALPOLE'S GOVERNMENT? THE BEES IN THE CRAFTSMAN}

An interesting interpretation of the Fable was offered by the weekly The country journal; or the craftsman. This periodical issued in Russell

\footnotetext{
${ }^{10}$ On 29 August, 1729, Brice's weekly journal linked Mandeville to the licentious system of freethinkers. On 27 March, 1731, the Fable was quoted in Read's weekly journal. The correspondent of Read's journal emphasized the role played by the Fable in spreading all sorts of vices in society, asserting that "[t]he ingenious Author of the Fable of the Bees seems to me to deserve a large Share of the Fame resulting from his noble Improvement of our Understanding [...] that the Drunkard, the Fop and other Extravagants, are the most useful Members of Society". On 11 September, 1731, the reporter for the Universal spectator and weekly journal, under the pseudonym Polydore Pert, represented Mandeville as the ideal successor of Epicurus and a patron of the libertines.
} 
Street began publication on 5 December, 1726, and originally appeared twice a week, presenting a political essay and a small number of advertisements. Starting in May 1727, the Craftsman began to be published once a week and changed its name to The country journal; or the craftsman. As some studies have demonstrated, the Craftsman was the mouthpiece of discontent regarding Walpole's government. The journal's editor was prosecuted for seditious libel on several occasions (Kramnick 1968, 17-23; Sanna 2006). The weekly was supported by influential politicians such as the Tory Henry St. John, Viscount Bolingbroke, and the Whig cousins William and Daniel Pulteney. Under the pseudonym of Caleb D'Anvers of Gray's Inn Esq., contributors to the Craftsman criticized the negative effects of Walpole's politics and expressed their distress in the face of what they saw as the corruption of society. The political aim of the Craftsman was stressed by its title, The country journal, a clear reference to the country party. ${ }^{11}$

This anti-ministerial weekly regularly identified the Fable with the government of the Prime Minister. The first reference to the Fable appeared in the Craftsman on 29 January, 1732. Under the pseudonym of Philantropus (and not Philantropos, i.e., Hutcheson), the Craftsman's author wrote to Caleb D'Anvers praising the role of charity. For Philantropus, charity consisted of public or private munificence aimed at meeting the needs or reducing the necessity or the distress of indigent people. In the present age, however, charity was endangered by the modern writers, who "have resolved it into the sordid Principles of Self-love, Ostentation and vain Glory". Although Philantropus did not mention the Fable explicitly, the reference to Mandeville's book was clear:

Besides, I take this Dispute about the Origin of moral Virtue to be only a meer Prevarication; an idle Contention and Battle of Words. It

\footnotetext{
${ }^{11}$ According to Bolingbroke, the partisan opposition between the Whigs and Tories had been replaced by court and country parties; the country party's aim was to unite the Whigs and Tories in opposition to Walpole and the court. The Craftsman's contributors therefore made continuous references to the republican tradition and the ancient constitution in the face of tyranny exerted by Britain's first minister. Because of its anti-ministerial bent, the Craftsman was often prosecuted by the government. In 1729 the Craftsman's printer, Richard Francklin, was brought to trial although he was acquitted by the jury. Two years later, Francklin was again arrested and imprisoned for printing "The letter from the Hague" in the Craftsman edition of 2 January, 1731. The letter, said to be written by Bolingbroke, accused Walpole of secret negotiations which lead to the second treaty of Vienna.
} 
said, for Instances, that Benevolence to others is the secret Offspring of Love to our selves; and what then?

Philantropus' reference obviously concerned the Fable's essay, An enquiry into the origin of moral virtues. In opposition to Mandeville, Philantropus distinguished between true and false charity: the first was aimed at bringing about positive effects in society, whereas the second was flawed by ostentation and vanity. For example, the South sea scheme was presented to public opinion as a charitable project because of its aim to reduce the public debt, but in reality it was motivated by private interests and the forces of corruption. In this sense, the false charity condemned by Philantropus seems related to Mandeville's view on charity. According to Mandeville, charity was not a virtue but proceeds from appetite of praise. Nevertheless, Philantropus asserted that the true charity was a virtue moved not from vanity but from public spirit.

On 26 February, 1732, the Craftsman published a letter addressed to Caleb D'Anvers. The letter was signed by an Old Whig who praised Caleb for his defense of the constitution and British freedom. Caleb's enemies were depicted by the anonymous author as supporters of the corruption represented by their patron, Robert Walpole:

Your Adversaries, on the contrary, are employed to commend every Action of their Patron, good or bad; to write Panegyrics upon the Vices of great Men; and according to their different Capacities, to worry every Body, who oppose their Master; [...] Thus they cry out that Mr. D'Anvers is abusing the Government [...] and were it not for his paper [The Craftsman], Nobody would have any Thing to say against the Government.

At this point, the Old Whig cited the Fable of the bees as the principal reference of the court administration and asserted that the wrong-headed opinions of the author of the Fable had been adopted by Walpole's establishment:

Your Antagonists, with the utmost Confidence, advanced the same Doctrines, viz. that Corruption, Venality and other Vices are become really necessary for the publick Good; meaning, I suppose, the Security of their Patron, and plead and harangue in their Behalf as if for our Benefit, in direct Opposition to all sense of Morality and Religion. These gentlemen seem to have made this Scheme of the Doctor's the ground of Work their performances for some time past. 
The Old Whig concluded that this perverse model had given rise to social incidents and tendencies over the past few years such as the South sea bubble and financial speculation. Four months later, Mandeville's text was mentioned again in Richard Franklin's weekly when the Craftsman published a letter by Anglicanus addressed to Caleb, which came to the conclusion that the Fable was detrimental to the interest of society. ${ }^{12}$ The Craftsman's correspondent was of the opinion that "nothing hath given more Offence in that Book than the Author's attempt to prove that moral Virtue hath no better an Origin than the Contrivance and Management of crafty politicians". In this case as well, Anglicanus' reference was directed to An enquiry into the origin of moral virtue, wherein Mandeville stated that virtues were the political offspring which flattery begot upon pride. In fact, from Anglicanus' point of view, the ancient lawgivers had originally exercised significant improvement on morality, but it was clear that the conduct of the modern politicians was characterized by corruption and self-interest rather than morality and virtue. Therefore, he concluded that "if therefore moral Virtue was first introduced into the World by the Craft of these Gentlemen, we ought to lament their present Degeneracy and endeavour to make Them honest by Necessity". Anglicanus' nostalgia for a virtuous and traditional society was a common theme among these patriots, who stressed the importance of moral virtues and the ancient constitution. In keeping with this, Walpole's opponents associated Mandeville's arguments about the a-moral genesis of society and toleration for vice with the current administration.

\section{CONCLUSION}

As Mandeville himself noted (1924, I: XV), his text was condemned by thousands who never actually read a word of it. Thanks to the press, the Fable became one of the most notorious works of the early eighteenth century. From the indictment of the Grand Jury until Mandeville's death, the Fable was a Leitmotiv in the newspapers of the time. The spread of the Fable was not limited to the metropolitan area of London; it also had reverberations in Dublin and Edinburgh. As I have shown, the dissemination of the Fable took place through multiple journalistic styles: editorials, advertisements and commentary. In all of these instances, however, it is noteworthy that the British press concentrated nearly all of his reportage and comments on the 1723 edition and rarely

\footnotetext{
${ }^{12}$ Anglicanus' letter appeared in the Craftsman of 24 June, 1732.
} 
paid attention to the second part of the Fable. Overall, the assessment of Mandeville's text provided by the press was largely negative. Journalists and contributors expressed a moral condemnation of the Fable, associating it with several negative topics such as the South sea bubble or the thief Jonathan Wild. Indeed, the denial of virtues, libertinism, atheism, the legalization of prostitution, and the praise of self-interest were the common topics associated with the Fable in the British papers.

My study of Mandeville's reception in the press sheds some light on the controversial issue of Mandeville's party affiliation (Dickinson 1976; Goldsmith 1985; Mitchell 2003). ${ }^{13}$ The British newspapers often granted a specific political stance to the Fable and its ideas. Mandeville himself in his Letter to Dion, invited his readers to pay attention to this new media, warning them about the contradictions of our party-affiliated writers. Indeed, the most extensive criticisms of his work came from partisan papers such as the Mist weekly journal, the Craftsman and the London journal. The Country newspapers saw the Fable as the main sponsor of Walpole's entourage and symbol of the degeneration of the times. The Whig press criticized the Mandevillean pessimism on the relationship between virtues and commerce. The Jacobite periodical, on the other side, associated Mandeville's text with the Whig Party which was depicted as a site for all manner of criminal and dishonest activities. Consequently, it stands to reason that partisan newspapers associated the Fable with whatever political views they themselves opposed in order to defame their antagonists. In doing so, the press indirectly demonstrated how the Fable first rose to public attention as a result of being implicated in a debate over the nature of politics.

\section{REFERENCES}

Black, Jeremy. 1987. The English press in the eighteenth century. London: Croom Helm. Carrive, Paulette. 1980. Bernard Mandeville. Passions, vices, vertus. Paris: Vrin.

Clark, C.E. 1994. The public prints. The newspaper in Anglo-American culture, 16651740. New York: Oxford University Press.

Dickinson, H.T. 1976. Bernard Mandeville. An "independent Whig". Studies on Voltaire and the Eighteenth Century, 152: 559-570.

Goldsmith, Maurice M. 1985. Private vices, public benefits: Bernard Mandeville's social and political thought. Cambridge: Cambridge University Press.

\footnotetext{
${ }^{13}$ Mandevillean scholars have already emphasized the Whig attitude of the Dutch author. Nevertheless, there is an ongoing debate regarding the nature of Mandeville's Whig affiliation: Court Whig, Country Whig or independent Whig.
} 
Harris, Michael. 1987. London newspapers in the age of Walpole: a study of the origins of the modern English press. London: Associated University Presses.

Harris, Michael. 2003. Print in neighborhood commerce: the case of Carter lane. In The London book trade. Topographies of print in the metropolis from the sixteenth century, ed. Robin Myers, Michael Harris, and Giles Mandelbrote. London: British Library Board, 45-69.

Hendley, William. 1713. Whigs no Christians. A sermon preach'd at Putney, in Surry, Jan. 30. 1712/3. Being the anniversary of the martyrdom of K. Charles the First of ever-blessed memory. London: printed for J. Morphew.

Heyd, Uriel. 2012. Reading newspapers: press and public in eighteenth-century Britain and America. Oxford: Voltaire Foundation.

Holmes Geoffrey, and Speck William. 1967. The divided society: party conflict in England 1694-1716. London: Edward Arnold.

Kaye, F.B. 1921. The writings of Bernard Mandeville: a bibliographical survey. The Journal of English and Germanic Philology, 20 (4): 419-467.

Kramnick, Isaac. 1968. Bolingbroke and his circle. The politics of nostalgia in the age of Walpole. Cambridge (MA): Harvard University Press.

Mandeville, Bernard. 1924 [1714-1732]. The fable of the bees: or private vices, publick benefits, ed. F.B. Kaye, 2. vols. Oxford: Oxford University Press.

Mandeville, Bernard. 1732. A letter to Dion, occasion'd by his book call'd Alciphron, or the minute philosopher. London: printed for J. Roberts.

Mitchell, Annie. 2003. Character of an independent Whig. "Cato" and Bernard Mandeville. History of European Ideas, 29, 291-311.

Nichols, John. 1812-1815. Literary anecdotes of the eighteenth century, 9 vols. London: printed for J. Nichols.

Plomer, Henry Robert. 1922. A dictionary of the printers and booksellers who were at work in England, Scotland, and Ireland from 1688 to 1725. Oxford: Oxford University Press.

Raymond, Joad. 1999. News, newspapers, and society in early modern Britain. London: Frank Cass.

Sakmann, Paul. 1897. Bernard de Mandeville und die Bienenfabel-Controverse. Eine Episode in der Geschichte der englischen Aufklärung. Leipzig: Mohr.

Sanna, Guglielmo. 2006. Il Craftsman. Giornalismo e cultura politica nell' Inghilterra del Settecento. Milano: Franco Angeli.

Sanna, Guglielmo. 2012. Religione e vita pubblica nell'Inghilterra del'700. Le avventure di Benjamin Hoadly. Milano: Franco Angeli.

Schneider, Louis. 1987. Paradox and society: the work of Bernard Mandeville. New Brunswick, NJ: Transaction books.

Siebert, F.S. 1965. Freedom of the press in England, 1476-1776; the rise and decline of government controls. Urbana: University of Illinois Press.

Simonazzi, Mauro. 2008. Le favole della filosofia. Saggio su Bernard Mandeville. Milano: Franco Angeli.

Speck, William. 1978. Bernard Mandeville and the Middlesex Grand Jury. Eighteenth Century Studies, 11 (3): 362-374.

Speck, William. 1986. Politics and the press. In The press in English society from the seventeenth to nineteenth centuries, ed. Michael Harris and A. J. Lee. London: London and Toronto University Press, 47-63. 
Stafford, J. Martin. 1997. Private vices, publick benefits? The contemporary reception of Bernard Mandeville. Solihull: Ismeron.

Tolonen, Mikko. 2013. Mandeville and Hume: anatomists of civil society. Oxford: Voltaire Foundation.

Matteo Revolti is a $\mathrm{PhD}$ candidate in history at the Goethe University Frankfurt am Main. His current research is focused on the public debate concerning The fable of the bees in Great Britain from 1714 to 1733.

Contact e-mail: <matteo.revolti@gmail.com> 